\title{
Analysis of Tourism Demand Cointegration from China to Indonesia
}

\author{
Sarwoko Sarwoko, Ridwan Ridwan, Henry Sarnowo \\ Faculty of Economics and Business \\ Universitas Janabadra \\ Yogyakarta, Indonesia \\ sarwoko@janabadra.ac.id, ridwan@janabadra.ac.id \\ henry_sarnowo@janabadra.ac.id
}

\begin{abstract}
Tourism Industry has been an important contributor to Indonesia Economy. The purpose of the empirical research in this paper is to investigate the existence of cointegration between China tourism demand in Indonesia with several macroeconomic factors like as real GDP per capita of the China, relatif price, exchange rate and trade openess using annual data spanning 2000-2018. Augmented Dikey-Fuller, Phillip Peron and Johansen's maximum likelihood tests are used to test for unit root and cointegration. An error correction model is estimated for an explain the short run China tourism demand to Indonesia.The result shows that the long run equilibrium exist among endogen variables and China tourist seems to be highly sensitive to the real GDP per capita, relatif price, exchange rate and trade openness with the signs like as the expectation. The implies of this study is that Indonesia government should arrange macroeconomic policies to sustain International tourism demands, especially from China.
\end{abstract}

Keywords: Tourism Industry, demand cointegration, GDP per capita, exchange rate relatif price

\section{INTRODUCTION}

As one of the important sectors of the national economy, tourism is considered to be an important tool in economic growth. Tourism functions as an actor to stimulate both local and regional socio-economic development at both the micro and macro scale [1]. The development of tourism cannot be separated from the process of globalization. The term was first used in the early 1950s to recognize the increasing interdependence of economies and societies around the world. Globalization, however, has existed for centuries by developing trade routes, including slave trade, colonization, and immigration.

Spatially, the relationship between tourism and economic growth concerns two ways of interaction from tourism to economic growth and from economic growth to tourism [2]. The tourism industry significantly contributes to economic growth [3]. On the other hand, investments in tourism and the number of foreign tourists are determinants of national income [4].

In Indonesia, tourism began to develop in the late 1980s. Tourism was deliberately developed as a measure to adjust to government policies in restructuring the national economy, especially from the service sector due to an "external shock" marked by a world recession and falling world oil prices.
Between 1970 and 1986, government revenues were focused on the oil and gas sector. However, since 1986 government revenue has shifted from the oil and gas sector to the non-oil and gas sector. The structure of the Indonesian economy, which was previously dominated by agriculture, manufacturing and mining, has now shifted towards services including the tourism sub-sector [5]. Tourism activities really play a significant role in the overall performance of the Indonesian economy [6].

Regionally, the tourism demand from the top ten countries of origin for tourists to Indonesia can be described as follows: the development of the flow of foreign tourists with the highest number is China, followed by Australia and Malaysia. If you look at the average flow of visits over the last ten years, Singapore ranks first followed by Malaysia, Australia, China and Japan. The most frequent (stable) tourist arrivals to Indonesia come from Singapore, Japan and South Korea.

Of all the countries of origin of tourists, the phenomenon of tourists from China to Indonesia needs special attention. China can be said to be a newcomer in its tendency to bring in the flow of tourist visits to Indonesia. The growth in the flow of tourist arrivals from China from 2001 to 2019 was almost 7 times with an average growth of 38.06 percent per year and in 2014 it was the fourth contributor to foreign exchange after Australia, Malaysia, Singapore, over Japan.

The purpose of this study is to examine the long-term relationship between tourism demand from China to Indonesia with macroeconomic variables, such as real GDP per capita, relative prices, the rupiah exchange rate and trade openness.

In general, the literature on tourism demand modeling focuses on analyzing the impact of the determinants and / or forecasting of accurate tourism demand. Over the past two decades, sophisticated econometric techniques have also played a vital role in understanding tourists' behavior and their demand for tourism products / services. Discussions about model specifications have been widely available in literature, for example [7], [8], [9], and [10], [11].

In the analysis of the international tourism demand model, most of the previous studies used a macroeconomic approach, mainly examining the income and price elasticity of tourism demand from origin to destination countries. Furthermore, many studies use a combination of time series data, as it is possible to estimate the elasticity of income, price and other important variables. This kind of research approach can be linked to research from [12]; [13]. Since then many studies 
that have followed have included standard factors to explain international tourism demand. These factors are the income of the country of origin (most of the income per capita), the difference in prices (the ratio of the consumer price index between the country of origin and the country of destination or sometimes multiplied by the exchange rate), the cost of travel (in terms of flights, visas and insurance), population, exchange rate differences, and destination competitors.

The results of a study [14] investigating the flow of international tourist arrivals to Australia found that income, real exchange rates and airfare were all inelastic to tourism demand both in the short and long term. Likewise, [15] improved the model for international tourism demand, classified into tourist origin, by applying time series data to the case studying Spain. Meanwhile [16] examined the demand for Tenerife Tourism using panel data. They suggest that the incoming international tourism demand turns out to be income elastic, but not elastic with prices and travel costs respectively. The study [17] found the exchange rate to be the main determinant of tourism demand in developed countries and proposed that the elasticity of the exchange rate is almost one.

\section{METHOD}

In this study, the variables used in the flow of tourist visits as the dependent variable and macroeconomic variables such as real GDP per capita of China, real GDP per capita of Indonesia, the real exchange rate of the rupiah against the Chinese currency, relative prices of tourism goods and services. between Indonesia and China, and Indonesia's openness of international trade as independent variables.

This study uses secondary data and time series 2000 2018. Statistical data on the flow of tourist visits from China to Indonesia, real GDP per capita from China, real GDP per capita from Indonesia, the real exchange rate of the rupiah against the Chinese currency, prices relative tourism goods and services between Indonesia and China, and Indonesia's international trade openness.

The form of function commonly used to analyze tourism demand is a linear function as follows:

$$
\operatorname{Arkun}_{t}=\alpha_{0}+\alpha_{1} G_{1 P}+\alpha_{2} G D P P_{2}+\alpha_{3} R_{1}+\alpha_{4} R_{2}+\alpha_{5} T+\mu
$$

where:

Arkun $_{t}$ is the flow of Chinese tourist visits to Indonesia in year $t$; GDP 1 is China's Real Gross Domestic Product per capita in year $t ; \mathrm{GDP}_{2}$ is Indonesia's Real Gross Domestic Product per capita in year $t ; \mathrm{R}_{1}$ is the real exchange rate of the rupiah against the Chinese Yuan in year $t ; \mathrm{R}_{2}$ is relative prices of Indonesian tourism goods and services year $t$, which are expressed in the ratio of the Indonesian state goods and services price index to China's goods and services price index: $\left(\mathrm{CPI}_{\text {Ind }} / \mathrm{CPI}_{\text {China }}\right)$; $\mathrm{T}$ is trade openness is determined by the ratio of export-import to Indonesia's gross domestic product.

\section{RESULTS AND DISCUSSION}

As shown in Table 1 is the estimation result of the error correction vector dynamic equation (VECM) of the flow of Chinese tourist visits to Indonesia. From Table 1 it can be shown that for tourists from China, in the pandek term, the independent variables have no effect on the flow of tourist arrivals from China. As much as $24.22 \%$ (Adj. R-squared, ${ }^{-} \mathrm{R} 2$ $=0.242245$ ) changes in the flow of tourist visits, can be explained by changes in the determining variables.

Table 1. ECM Estimation of Flow of Chinese Tourist Visits to Indonesia, 2000-2018

\begin{tabular}{|c|c|c|c|c|}
\hline Variable & Coeffisien & Std. error & t-statistic & Prob. \\
\hline $\mathrm{C}$ & -0.831836 & 0.928255 & -0.896130 & 0.0894* \\
\hline $\operatorname{LnGDP}_{1 t-1}$ & 13.06550 & 10.48501 & 1.246112 & $0.0386 * *$ \\
\hline $\operatorname{LnGDP}_{2 t-1}$ & 0.534675 & 2.040588 & 0.262020 & 0.7981 \\
\hline $\operatorname{LnR}_{1 t-1}$ & 0.171236 & 2.017567 & 0.084873 & 0.9339 \\
\hline $\mathrm{R}_{2 \_a t-1}$ & -0.010005 & 0.018554 & -0.539225 & 0.6005 \\
\hline$T_{t-1}$ & -0.960072 & 0.307798 & -3.119164 & $0.0098 * *$ \\
\hline R-squared & 0.479044 & \multirow{2}{*}{\multicolumn{2}{|c|}{$\begin{array}{l}\text { Mean dependent variable } \\
\text { S.D. dependent variable }\end{array}$}} & 0.280908 \\
\hline Adj. R-squared & 0.242245 & & & 0.858279 \\
\hline
\end{tabular}

*significant at the $1 \%$ level; **significant at the $5 \%$ level

The Correction Vector Coefficient measures the speed at which imbalances are adjusted in the short run. The Correction Vector Coefficient has a negative and significant direction with a value of 0.960072 . This shows that $96.01 \%$ of the imbalance will be corrected in the short term, less than one year and the long-term relationship between the flow of tourist visits and its determinants is relatively stable.

Variables such as real GDP per capita of countries of origin of tourists, rupiah exchange rate, cost of living or prices of tourism services and trade openness are thought to have a strong influence on the flow of tourist arrivals from that country. The ECM estimate is used to explain the tourism demand from China. The regression results show that there is a long-term balance between endogenous variables and the flow of tourist arrivals from that country (China) with an intensity that is very sensitive to changes in China's real per capita income, the rupiah exchange rate with the Chinese Yuan and Indonesia's trade openness and the cost of living or inflation.

In the long term, to attract more Chinese tourists so that Indonesia remains the main alternative tourist destination for them when their income rises, then as a supplier of tourism products, Indonesian tourism stakeholders must improve services to tourists, improve the quality of tourism products and enhance the associated brand image. future policy implications. The coefficient of real GDP per capita is elastic with a negative sign. This shows that for Chinese tourists, traveling to Indonesia is still an inferior thing, not a top priority.

In the long run, the rupiah exchange rate against the Chinese yuan has implications for the arrival of Chinese tourists. Therefore, monetary authorities such as Bank Indonesia must maintain the stability of the rupiah exchange rate against the Chinese yuan, for example by implementing forward interventions to balance demand and supply of 
foreign exchange in the forward market. Basically, any depreciation of the rupiah against the Chinese yuan must be issued with the right policies so as to increase the value of the rupiah.

The elasticity of the rupiah exchange rate against the flow of Chinese tourist visits has an elastic intensity in a positive direction. Furthermore, the openness of the trade economy (Trade Openess) also has implications for the flow of tourist arrivals from China. Therefore, government policies concerning exports and imports must be able to encourage our exports abroad.

The elasticity of the openness of the trade economy to the flow of Chinese tourist arrivals has an elastic intensity in a positive direction. This shows that local products are preferred over imported products for Chinese tourists to Indonesia. Finally, the increase in the cost of living (inflation) in Indonesia has hampered the flow of Chinese tourist visits to Indonesia. Therefore, the government needs to maintain price stability or inflation by using both monetary policy and fiscal policy. The elasticity of the ratio of the cost of living of Indonesia-China to the flow of Chinese tourist arrivals has an inelastic intensity with a negative direction. Changes in the cost of living that are more expensive do not really affect the flow of Chinese tourists visiting Indonesia.

\section{CONCLUSION}

This paper describes the use of cointegration and error correction models to see the long and short term relationship between the determinants and the flow of tourist arrivals from China. Variables such as real GDP per capita of countries of origin of tourists, rupiah exchange rate, cost of living or prices of tourism services and trade openness are thought to have a strong influence on the flow of tourist arrivals within the country. Annual data from 2000-2018 were used for analysis. Augmented Dikey Fuller (ADF test) and Phillip-Peron (PP test) unit root tests as well as the Johansen maximum likelihood test were used to test for staisonarity and cointegration on these variables. The ECM estimate is used to explain the tourism demand from China. The results of the discussion show that there is a long-term balance between endogenous variables and the flow of tourist visits from that country (China) with an intensity that is very sensitive to changes in China's real per capita income, the rupiah exchange rate with the Chinese yuan and Indonesia's trade openness and the cost of living or inflation. .

\section{ACKNOWLEDGMENT}

Thanks for comments and suggestions from reviewers and audiences of The 3rd International Conference on Banking, Accounting, Management, and Economics (ICOBAME) 2020.

\section{REFERENCES}

[1] Algieri, B., Perkiraan ekonometrik dari permintaan untuk pariwisata: kasus Rusia.Ekonomi Pariwisata, 12 (1), 5-20, 2006

[2] Amaluddin, Amaluddin, The Nexus between Tourism Development and Economic Growth in Eastern Indonesia: A Panel Vecm Approach 3,
2019). Available at SSRN: http://dx.doi.org/10.2139/ssrn.3591573, 2019.

[3] Seetanah, B., Assessing the dynamic economic impact of tourism for island economies.Annals of Tourism Research 38(1):291-308 DOI: 10.1016/j.annals.2010.08.009, 2011.

[4] Kar, M., Zorkirisci, E., \& Yıldırım, M., Turizmin Ekonomiye Katkıs Uzerine Ampirik Bir Değerlendirme. Akdeniz University Faculty of Economics \& Administrative Sciences Faculty, 2004.

[5] Republik Indonesia, Nota Keuangan dan RAPBN 1993/1994

[6] Smeral, E., Peramalan pariwisata dunia - pertahankan cepat, sederhana dan kotor. Ekonomi Pariwisata,13 (2), 309-317, 2007.

[7] Katafono, R. and Aruna Gounder, "Modelling Tourism Demand in Fiji". Working Paper. Economics Department Reserve Bank of Fiji Suva, Fiji, 2004

[8] Bechdolt, B.V., Cross-Sectional Travel Demand Function: U.S. Visitor to Hawaii. 1961-1970. Quarterly Review of Economics and Business, 13(4): 13-17, 1973.

[9] Loeb, P.D., International Travel to the United State: An Econometric Evaluation. Annal of Tourism Research, 9: 7-20, 1982.

[10] Chadee dan Mieczkoski, An Empirical Analysis of the Effect of Exchange Rate on Canadian Tourism. Journal of Travel Research. 26(1): 13-17, 1987.

[11] Sheldon, P.J., 'Forecasting tourism: expenditure versus arrivals', Journal of Travel Research, Vol 32, pp 13-20, 1993.

[12] McAleer, M., Sherlock Holmes and the search for truth: A diagnostic tale. Journal of Economic Surveys, 8(4), 317- 370, 1994.

[13] Lim, C., Review of international tourism demand models. Annals of Tourism Research, 24(4), 835-849, 1997.

[14] Seetaram,Tourism Indicators, Australia https://www.abs.gov.au/ausstats/abs@.nsf/featurearticlesbyCatalogue/45 61D5C278B7720FCA256A7D001DD82 C?OpenDocument, 2000.

[15] Holik, A., Relationship of Economic Growth with Tourism Sector JEJAK: Jurnal Ekonomi Dan Kebijakan, 9(1), 16-33. doi:http://dx.doi.org/10.15294/Jejak.v9i1.7184, 2016.

[16] Lan, Yu-Wei, Dan Lin and Lu Lin, Cointegration analysis of tourism demand by Mainland China in Taiwan and stock investment strategy,Journal of Economic and Financial Studies (JEFS), LAR Center Press, vol. 3(5), pages 1-9, October, 2015.

[17] Ketenci, Natalya, Cointegration analysis of tourism demand for Turkey. Applied Econometrics and International Development 10(1) - January. 2010 